\title{
La imagen de las personas racializadas y la construcción del sujeto negro: el racismo y la agencia través de la mirada de los viajeros en el siglo XIX colombiano*
}

\section{Resumen}

Este artículo analiza como la literatura de viajeros, a través de recursos visuales y letrados, construyó una representación del sujeto negro en la Colombia del siglo XIX a partir de nociones sobre raza, geografía y civilización. Ideologías como el determinismo geográfico y el racismo científico alimentaron la representación de los afrodescendientes como seres inferiores, salvajes e insubordinados, que, además, constituían una tala para el progreso del país. Los viajeros europeos, en particular, elaboraron estas representaciones con el ánimo de justificar las aventuras imperiales necesarias en el marco de la Revolución Industrial. En ese sentido, establecieron los nuevos términos de la relación de dominación colonial entre Europa y las nuevas repúblicas americanas. A pesar de la relación asimétrica entre viajeros y locales, los últimos negociaron los términos de la interacción y desafiaron los marcos de interpretación de los primeros. Para reconstruir la agencia de los sujetos negros proponemos un giro metodológico que hace énfasis en la lectura de los instantes en los cuales lo nativos actuaron en contravía de los preconceptos y las jerarquías socioraciales de la época.

\section{Palabras clave}

Tesauro: racismo, agencia.

Autor: viajeros, cultura visual, cultura letrada, representaciones.

Referencia bibliográfica para citar este artículo: Deavila Pertuz, Orlando y Guerrera Mosquera, Andrea. "La imagen de las personas racializadas y la construcción del sujeto negro: el racismo y la agencia través de la mirada de los viajeros en el siglo XIX colombiano". Anuario de Historia Regional y de las Fronteras 26.2 (2021): 287-315.

Fecha de recepción: $1 / 12 / 2020$

Fecha de aceptación: 16/03/2021

Orlando Deavila Pertuz: PhD. in Latin American History, University of Connecticut. Profesor auxiliar e investigador del Instituto Internacional de Estudios del Caribe, Universidad de Cartagena. Correo electrónico: odeavilap@unicartagena.edu.co. Código ORCID: 0000-0002-7675-0575.

Andrea Guerrero Mosquera: $\mathrm{PhD}$ en Humanidades, línea en Historia por la Universidad Autónoma Metropolitana- Iztapalapa. Profesora Universidad del Tolima. Correo electrónico: paguerrerom@ut.edu.co. Código ORCID: 0000-0002-3152-1883.

\footnotetext{
* El artículo fue fruto de un proyecto independiente y no contó con financiación institucional.
} 


\title{
Representing the Black Subject and Racialized Peoples: Racism and Agency through the Gaze of the Travelers in Nineteenth Century Colombia
}

\begin{abstract}
This article analyzes how the travel literature, through literary and visual resources, made a representation about black individuals during Nineteenth-century Colombia based on notions of geography, race, and civilization. The leading ideologies at the time, such as geographical determinism and scientific racism, led the people of African descent to be represented as savages, insubordinate, and inferior beings and to be deemed as obstacles to the country's progress. European travelers in particular made these representations to justify the imperial adventures necessary within the context of the Industrial Revolution. Therefore, they helped to establish a new relationship of colonial domination between Europe and the new American republics. Despite the uneven relation between travelers and locals, the latter was able to negotiate the terms of the interactions and used to challenge the travelers'framework of interpretation. To unveil the local's agency, this article proposes a methodological turn that emphasizes the moments where natives acted against standing pre-concepts and socio-racial hierarchies.
\end{abstract}

Keywords

Tesauro: Racism, Agency.

Author: Travelers, Visual Culture, Literary Culture, Representations.

\section{Representando o Sujeito Negro e as pessoas racializadas: Racismo e Agência através dos Viajantes na Colômbia do século XIX}

\section{Resumo}

Este artigo analisa como a literatura de viagem, por meio de recursos literários e visuais, fez uma representação sobre as pessoas afrodescendentes no século XIX na Colômbia a partir de noções de geografia, raça e civilização. As principais ideologias da época, como o determinismo geográfico e o racismo cientifico, levaram os afrodescendentes a serem representados como selvagens, insubordinados e inferiores e como obstáculos ao progresso do país. Os viajantes europeus, em particular, fizeram essas representações para justificar as aventuras imperiais necessárias no contexto da Revolução Industrial. Portanto, ajudaram a estabelecer uma nova relação de dominação de Europa sobre as novas repúblicas americanas. Apesar da relação desigual entre viajantes e habitantes locais, estes últimos foram capazes de negociar os termos das interações e costumavam desafiar a estrutura de interpretação dos viajantes. Para desvendar a agência do local, este artigo propõe uma virada metodológica que enfatiza os momentos em que os nativos agiram contra pré-conceitos e hierarquias sócio-raciais.

Palavras-chave

Tesauro: racismo, agência

Autor: viajantes, cultura visual, cultura literária, representações. 


\section{Introducción}

Las representaciones son el conjunto de imágenes y estereotipos elaborados a partir de la interacción entre sujetos sociales. Aunque se alimentan de la experiencia cotidiana, estas también se producen con base a marcos ideológicos preconcebidos y transferidos socialmente. Al asignarle atributos e identidad a los sujetos, las representaciones permiten ordenar la sociedad y agrupar a las personas acorde con características predeterminadas, y se convierten en un mecanismo de regulación toda vez que ayudan a situar a individuos y grupos dentro de la sociedad. Aunque también ocurran en el plano individual, se convierten en un hecho social cuando son adoptadas por grupos hegemónicos y utilizadas para justificar la subordinación de otros. En consonancia con lo anterior, este artículo se propone examinar cómo a través del registro visual y escrito se construyó la representación del "otro"- en este caso, el sujeto negro colombiano del siglo XIX - en el marco de un contexto histórico dominado por relaciones de poder desiguales y por la existencia de estructuras ideológicas y materiales como la esclavitud, el imperialismo y el racismo.

En este artículo se hará un acercamiento a la cultura visual, un campo de estudio que generalmente pone en diálogo los estudios culturales, la historia del arte, la teoría crítica y la antropología. Asimismo, se articulará el estudio de la cultura visual con la interpretación de la cultura letrada, es decir, la literatura de viajeros; dado que, por medio de estas dos vertientes se puede explorar una visión y un sentido de lo social, histórico, cultural, ético, moral, social y religioso, que han influido en la forma en como se ha representado la imagen del sujeto negro. Poner en diálogo lo escrito con lo gráfico es posible, dado que, por lo general, lo primero antecede a lo segundo en la literatura de viajeros. Muchas de las láminas, grabados e incluso acuarelas, se realizaban con base a las descripciones del viajero. Esto es revelador porque demuestra que muchas de las imágenes correspondían a una visión mediada por varios puntos de vistas e incluso el desconocimiento mismo de los lugares. Por tanto, las preconcepciones y los prejuicios definían aquellas representaciones del sujeto negro. La cultura visual considera a las imágenes como un documento que está cargado de historia, por lo tanto, resguardan relatos y mensajes, y tiene como objetivo desarrollar y ampliar la comunicación en los individuos, al mismo tiempo que, permite que se lleve a cabo un aprendizaje colectivo, en este caso, del estereotipo del sujeto negro.

Muchas de las imágenes que han llegado a la actualidad no se realizaban in situ, sino que, se elaboraban tiempo después, pero con las indicaciones de los viajeros que trataban de ser un retrato cercano a la realidad, algo que se puede ver, por ejemplo, en la elaboración del rinoceronte de Durero. ${ }^{1}$ Este artista realizó un grabado a partir de una descripción escrita y un boceto elaborado por un tercero, quien pudo ver a un rinoceronte que había llegado de la India a Lisboa, es decir, Durero realizó esta icónica imagen renacentista sin haber viajado a Asia. Algo similar sucedió con Jacques de Sève quien fue la persona encargada de ilustrar la Histoire naturelle,

${ }^{1}$ María C Estivariz y María Alejandra Migoya , "Ilustrando la naturaleza", Museo, 3, 19 (2005): 90-95. 
générale et particulière de Buffon; él fue uno de los encargados de pintar albinos y personas con manchas en la piel (vitiligo) en América durante el siglo XVIII. ${ }^{2}$ Con lo anterior, no se pretende restar importancia a la imagen, sino ver el contexto en el que se produjeron dichas imágenes, al igual que las descripciones.

También se quiere proponer a las descripciones como un documento visual, en la medida que permite recrear lo no visto, a partir de los detalles escritos en los documentos de los viajeros. Esto se sabe, dado que, estos personajes no escatimaron en desmenuzar cada uno de los lugares explorados, sus pobladores y sus costumbres; todo lo anterior, con la finalidad de dejar un registro de lo visto y no visto, es decir, desde las impresiones que tenía acerca de los lugares que no conocían, pero que poco a poco exploraron capa por capa. En dichas exploraciones se acercaron a lo que no conocían con lentes eurocéntricos, letrados y civilizatorios, tres características que son fundamentales para entender el desarrollo de los textos que se pueden encontrar para la época, al mismo tiempo que permiten establecer algunas relaciones y similitudes con eventos parecidos en otros contextos.

La literatura de viajeros es útil para reconstruir las representaciones del sujeto negro en el curso del primer siglo de la república. Los viajeros, en su mayoría provenientes de Europa, elaboraron descripciones detalladas del país y de su gente. A diferencia de los discursos oficiales de la época, no silenciaron lo racial y, por el contrario, se esmeraron en reconstruir la composición demográfica, las relaciones socio-raciales, el lugar público de los afrodescendientes y los cambios que los mismos experimentaron desde el establecimiento de la república. Estas representaciones estaban mediadas por los preconceptos y doctrinas racialistas que reinaban en Europa, al igual que por las estructuras ideológicas del imperialismo y la esclavitud. Como se verá a continuación, estos viajeros representaron al sujeto negro como un "otro" inferior, indómito - a veces ingenuo - y carentes de los mínimos necesarios para la vida civilizada o la república.

Parafraseando a Mary Louise Pratt, la interacción entre viajeros y locales durante el siglo XIX constituye un ejemplo de una "zona de contacto", es decir, un espacio social o de "encuentro colonial" en el cual diferentes culturas se encuentran o colisionan, y cuya interacción se rige por relaciones asimétricas de dominación y subordinación. ${ }^{3}$ Las representaciones alimentan estas relaciones y, a su vez, son reelaboradas dentro del mismo contexto. Sin embargo, los locales no eran sujetos pasivos y regularmente desafiaban los marcos de interpretación de los viajeros. Como se demostrará, algunos de estos anotaron con asombro o preocupación la activa participación de los sujetos negros en la vida pública del país, dado que, ocupaban cargos políticos o militares. Algunos viajeros vieron sus representaciones desafiadas en encuentros cotidianos donde los locales dominaron los términos de la interacción

\footnotetext{
${ }^{2}$ Georges Louis Leclerc de Buffon, Histoire naturelle, générale et particulière (Paris: Nouvelle Société Typographique, 1785), 278-290.

3 Mary Louise Pratt, Imperial Eyes: Travel Writing and Transculturation (London and New York: Routledge, 1992), 4-6.
} 
y cuestionaron la jerarquía que los primeros creían indiscutible. Para identificar estos momentos es necesario deconstruir el discurso y "voltear la mirada" (turn the gaze), como sostiene Mimi Sheller. ${ }^{4}$ Se trata de identificar la voz del "otro" a través de los instantes en los cuales la jerarquía era contestada por los locales. Por medio de estas formas cotidianas de resistencia, ${ }^{5}$ los nativos problematizaron las representaciones hechas sobre sus cuerpos. Esta apuesta metodológica es necesaria para entender que los encuentros no siempre eran verticales, muy a pesar de las inequidades en capital cultural, social y económico que existían entre los viajeros y los locales. Leer la literatura de viajeros desde esta perspectiva teórica y metodológica nos permite neutralizar los sesgos y silencios que caracterizaron a la producción de documentos históricos sobre la negrura en Occidente. ${ }^{6}$

Los trabajos en torno a la literatura de viajeros en Colombia han examinado las percepciones que los mismos tenían sobre la geografía natural y humana, ${ }^{7}$ la vida cotidiana y la sociabilidad, ${ }^{8}$ y la transición política hacía la república. Algunos autores han demostrado que los viajeros obraron como exploradores de nuevos recursos económicos y mercados para los países europeos inmersos en los inicios de la Revolución Industrial ${ }^{9} \mathrm{y}$, de ese modo, contribuyeron a forjar una nueva relación colonial entre las potencias europeas y Colombia. Este "nuevo descubrimiento de

\footnotetext{
${ }^{4}$ Mimi Sheller, Citizenship from Below. Erotic Agency and Caribbean Freedom (Durham: Duke University Press, 2012), 213-214.

${ }^{5}$ James C Scott, Los dominados y el arte de la resistencia. Discursos ocultos (Ciudad de México: Ediciones ERA, 2000), 233-238.

${ }^{6}$ Sobre los sesgos en la producción de fuentes, archivos y narrativas históricas ver Michel Rolph Trouillot, Silenciando el pasado. El poder y la producción de la Historia (Albolote: Comares, 2017).

${ }^{7}$ Gabriel Giraldo Jaramillo, "Viajeros franceses en Colombia", Estudios históricos (Bogotá, Ministerio de Educación Nacional, 1954): 187-212; Felipe Angulo, "Viajeros franceses del siglo XIX en Colombia. Un balance bibliográfico", http://www.afehc-historia-centroamericana.org/index_action_fi_aff_id_1649.html (Consultado el 15 de noviembre de 2020); Gómez García, Juan Guillermo. "Stübel y Reiss: dos viajeros alemanes en la Colombia del siglo XIX”, Boletín Cultural y Bibliográfico vol. 31, núm. 35, Bogotá, Banco de la República, 1994, pp. 3-27; Jaime Jaramillo Uribe, "La visión de los otros: Colombia vista por observadores extranjeros en el siglo XIX”, Historia Crítica, 1, 24, (2003): 7-21; Jorge Orlando Melo, "La mirada de los franceses: Colombia en los libros de viaje durante el siglo XIX", ponencia presentada en Simposio: Viajeros colombianos en Francia y franceses en Colombia, Paris, 2001; Ángela Rocío Mora, "Pasto y sus gentes en el siglo XIX: de la percepción de los viajeros a la construcción de un imaginario social en Colombia", Procesos Históricos, 21, (2018): 94-107. En una perspectiva novedosa, Adriano Guerra discute como las representaciones sobre el entorno ecológico, en este caso, los mosquitos, ayudaron a construir un imaginario sobre el trópico en el Caribe colombiano. Ver: Adriano Guerra, "El imperio invisible. Los mosquitos en el Caribe colombiano vistos por los viajeros extranjeros del siglo XIX", Memorias, 16, 41 (2020): 103-129.

${ }^{8}$ Marcela Camargo Mesa, "Viajeros europeos en Bogotá 1869-1900, experiencias de viaje y observación de la sociedad en las calles" (Monografía de pregrado para optar por el título de Historiador), Pontificia Universidad Javeriana, 2009.

${ }^{9}$ Viviana Olave Quintero, "Viajeros de la avanzada del capitalismo. La visión de Gaspard Théodore Mollien sobre la política de la Nueva Granada en la post-independencia", Historia y espacio, 5, 33 (2009): 5-20; Katherinne Giselle Mora Pacheco, "Monotonía, aislamiento y atraso agrícola. Descripciones de viajeros del siglo XIX e historia agraria de la Sabana de Bogotá (Colombia)", HiSTOReLo. Revista de Historia Regional y Local, 7, 14 (2015):180-213.
} 
América" ${ }^{10}$ condujo a la construcción de imaginarios y representaciones de los habitantes locales - con base en nociones de geografía, raza y civilización promovidas desde el siglo XVIII - y que fueron instrumentalizadas para justificar las aventuras imperiales en América. ${ }^{11}$ De manera similar, otros trabajos han analizado cómo viajeros provenientes del interior andino representaron a las geografías periféricas del país como parte integral de la nación, pero subordinadas ante la primacía de la región central; esto en virtud de su caracterización como geografías habitadas por seres racializados como inferiores. ${ }^{12}$ En los últimos años, nuevos trabajos han abordado la racialización e inferiorización de los cuerpos a partir de relatos construidos a través de los discursos de civilización y barbarie, y el conocimiento geográfico y antropológico de la época. ${ }^{13}$ Sin embargo, poco se ha dicho sobre cómo los viajeros, a través de la cultura visual y letrada, contribuyeron específicamente a la racialización de los cuerpos de los afrodescendientes, y muchos menos, cómo los últimos desafiaron aquellas representaciones. El trabajo de María Riaño hace una contribución en este sentido, y por demás, propone un giro metodológico para descentrar el relato hegemónico de los viajeros. De manera similar a la propuesta de Mimi Sheller, ${ }^{14}$ propone identificar los instantes en los cuales la agencia de los anfitriones se hizo visible, irónicamente, a través del mismo relato. ${ }^{15}$ En este caso, estudia la interacción entre viajeros y bogas en los champanes del Magdalena durante el siglo XIX y demuestra cómo gracias a la experiencia de estos últimos, y la inexperticia de los primeros, había un revertimiento en las estructuras de poder que favorecía a los bogas y que les permitía definir los términos de la interacción.

En este artículo se analizará más de una docena de viajeros que recorrieron el país entre 1823 y 1900, se dará prioridad aquellos que aludieron explícitamente a lo racial y que representaron a los afrodescendientes, esto, bajo la concepción de representar lo pintoresco, característica asociada a la mirada de los incivilizado

\footnotetext{
${ }^{10}$ Ángela Pérez Mejía, La geografía de los tiempos dificiles: escritura de viajes a Sur América durante los procesos de independencia 1780-1849 (Medellín: Universidad de Antioquia, Medellín, 2002).

${ }^{11}$ Camila Torres Torres, "La imagen de Bogotá construida por los viajeros extranjeros que recorrieron el país a lo largo del Siglo XIX" (Tesis de Maestría, Pontificia Universidad Javeriana, 2009) 271; Julián David Gallón, "El rio Magdalena. Visto por viajeros franceses e ingleses, 1823-1871." (Monografía de pregrado, Universidad de Antioquia, 2009), 151; Santiago Muñoz Arbeláez, "Las imágenes de viajeros en el siglo XIX: El caso de los grabados de Charles Saffray sobre Colombia", Historia y grafía, 34 (2010): 165-197; Álvaro Villegas, "El valle del río Magdalena en los discursos letrados de la segunda mitad del siglo XIX: territorio, enfermedad y trabajo", Folios, 39, (2014): 149-159.

${ }^{12}$ Diana Yaneth Ávila Camargo, "Relatos de viajeros colombianos: imaginarios, representación y territorio, 1850 - 1860" (Tesis de Maestría, Universidad Andina Simón Bolívar, 2012), 118; Leguis Gómez, "Clase, etnia y región: el Caribe Novogranadino y la mirada del 'Otro'. 1750-1830”, Artelogie. Recherche sur les arts, le patrimoine et la littérature de l'Amérique latine, 9 (2016): 1-28.

${ }^{13}$ Camilo Juan Niño Vargas, Indios y viajeros: Los viajes de Joseph de Brettes y Georges Sogler por el norte de Colombia 1892-1896 (Bogotá: Universidad de los Andes, 2017); Carla Gómez Creutzberg, Viajeros y espacios en disputa. Frederick A. A. Simons y el Caribe colombiano a finales del siglo XIX (Bogotá: Universidad Externado de Colombia, 2017).

${ }^{14}$ Sheller, Citizenship from Below, 214.

${ }^{15}$ María Camila Nieto Villamizar y María Riaño Pradilla, Esclavos, negros libres y bogas en la literatura del siglo XIX (Bogotá: Universidad de los Andes, 2011), 141-256; Rut Bibiana González Echeverry, "Relatos de viaje por Colombia, 1822-1837. Cochrane, Hamilton y Steuart", Historia y sociedad, 32 (2017): 317-51.
} 
y bárbaro. Como se sabe, la mayoría ingresaron por Cartagena y Santa Marta dos de los puertos más importantes para la época, por lo tanto, se hará énfasis en las descripciones de los sujetos negros del Caribe colombiano. De estos viajeros, tres son colombianos y procedían del interior andino. Compartían con sus pares extranjeros muchas de las representaciones sobre las personas afrodescendientes. En este caso, las mismas están mediadas por las geografías racializadas de la época que imaginaban las periferias del país como recodos inhóspitos, infestados de plagas y habitados por seres incivilizados. Sin embargo, es necesario advertir que los viajeros andinos tenían una agenda diferente a la de sus pares europeos o norteamericanos. Para ellos, estas representaciones no solo tenían como fin reconocer territorios susceptibles de ser incorporados a las redes de comercio, sino también reconocer las características geográficas y humanas del país, en aras de identificar los "tipos" que conformaban la sociedad nacional y sus atributos culturales. En lo que Pratt define como una práctica de "transculturación", los ilustradores americanos se apropiaron de los modos de representación producidos en el Atlántico Norte para interpretar su propia realidad y para justificar sus propias jerarquías. ${ }^{16}$

Es importante advertir que, más allá de reseñar las representaciones y estereotipos sobre lo afrodescendiente, elaborados a través de la cultura visual y letrada, lo que nos interesa es entender cómo y porqué los viajeros construyeron esa "gramática de la diferencia". En principio hay que decir que este contexto está marcado por dos hechos históricos: la Revolución Industrial en Europa que creó la necesidad de nuevos mercados para adquirir materia prima y para exportar productos manufacturados, y la independencia de las repúblicas americanas, que dio lugar a la creación de políticas para favorecer la exportación, la inmigración europea y, la inversión de capital extranjero. La coincidencia de ambos hechos dio lugar a una nueva fase de la expansión europea y a una nueva fase territorial del capitalismo, en la cual, los viajeros desempeñaron un papel clave. Estos debían interpretar el entorno para evaluar sus posibilidades de integración al sistema económico europeo. ${ }^{17}$ En consecuencia, muchos de estos viajeros describen los territorios americanos como lugares vírgenes - a pesar de las transformaciones dramáticas que habían experimentado el ecosistema durante el periodo virreinal - y cuya prosperidad dependía de la intervención civilizadora de Europa. Este tipo de representaciones, que Sheller enmarca dentro del "imperialismo romántico", reinventó América como un paraíso terrenal y a sus habitantes como sujetos sumidos en el ocio e incapaces de sacarle provecho a las riquezas naturales del entorno. ${ }^{18}$ Estas representaciones estereotipadas y asimétricas justificaron las aventuras comerciales y/o imperialistas del siglo XIX; por ende, los viajeros ayudaron a forjar, a través de la cultura visual y letrada, las relaciones de dominación colonial entre las potencias europeas y las repúblicas americanas. En ese sentido, se ha escogido el periodo que transcurre entre 1823 - cuando se consolida la independencia de la Gran Colombia y comienzan a llegar representantes de potencias europeas con el ánimo de forjar lazos comerciales

\footnotetext{
${ }^{16}$ Pratt, Imperial Eyes, 6.

${ }^{17}$ Muñoz Arbeláez, "Las imágenes de viajeros en el siglo XIX”, 174.

${ }^{18}$ Mimi Sheller, Consuming the Caribbean: From Arawaks to Zombies (Abingdon: Routledge, 2003), 37.
} 
y diplomáticos con el país - y 1900. Con el cambio de siglo, la literatura de viajeros como género literario comienza a decaer debido a la irrupción de nuevos medios de transporte y comunicación que permiten acceder con más facilidad a los territorios que antes se creían inexplorados o inaccesibles. Así mismo, la literatura de viajeros y su retórica costumbrista fue progresivamente superada por otras narrativas más elaboradas como el periodismo, la demografía y la etnografía. Por otro lado, el estallido de la Guerra de los Mil Días (1899-1902) llevó a que menos viajeros visitaran el país durante el curso de aquellos años. Los viajeros que llegaron a inicios del siglo $\mathrm{XX}$ vinieron con motivaciones diferentes - no necesariamente como representantes diplomáticos de otros países sino como viajeros independientes - y con marcos de interpretación diferentes a los que habían predominado en el siglo XIX.

Como hemos dicho, la mayoría de los viajeros que se analizaran a continuación llegaron al país precisamente con el fin de establecer lazos comerciales y diplomáticos entre sus países de origen y la nueva república. Carl August Gosselman y Francis Hall, que visitaron la Gran Colombia en sus primeros años, exploraron las posibilidades para el fomento del comercio o la inmigración de sus nacionales. El ingeniero inglés Lionel Gisborne visitó la región del Darién entre 1850 y 1852 en busca de una conexión entre las costas del Mar Caribe y el Océano Pacífico. Ya el geólogo alemán Julius Fröbel había llegado a Centroamérica, de donde partió hacia la Nueva Granada, motivado por los rumores de la apertura de un canal a través de Nicaragua. Algunos viajeros colombianos, como José María Samper y Nicolás Tanco, tenían intereses similares. Ambos viajaron al Viejo Mundo con el fin de expandir los horizontes comerciales de Colombia. Samper, en particular, creía fundamental que el país estrechara sus vínculos comerciales con Europa. Al igual que los viajeros provenientes del exterior, pensaban que el progreso de la nación solo sería posible si cediera a la influencia de la civilización europea.

\section{El sujeto negro como salvaje e incivilizado: descripciones de los viajeros del siglo XIX}

La centralidad de lo racial en los relatos elaborados por viajeros provenientes de Europa no fue algo fortuito, esto se debió a la vigencia de los postulados del determinismo racial, la descripción de los tipos raciales, el fenotipo y el racismo científico. Por eso, la percepción sobre las características conductuales de los sujetos aparecía con tanta frecuencia como la descripción de los paisajes, la vida cotidiana o las circunstancias políticas y económicas del momento. Como advertimos, las representaciones racializadas eran necesarias para justificar la dominación colonial que los viajeros elaboraban a través de sus relatos, además del exotismo que imprimían a sus descripciones y las (re)creaciones visuales. No obstante, para ellos no fue fácil ordenar una realidad social donde reinaba el mestizaje biológico y donde las categorías raciales eran imprecisas. Los cuerpos negros eran repetidamente estabilizados en la literatura de viajeros porque solían desafiar los esfuerzos de clasificación racial. ${ }^{19}$ Cuando Eliseo Reclus llegó a Cartagena en 1855 presenció la

\footnotetext{
${ }^{19}$ Sheller, Citizenship from Below, 235.
} 
contienda entre dos hombres que se batían a duelo en una plaza de la ciudad. Reclus describió a los contendores como "dos hombres de cabellos lisos, de mirada feroz, tez de color indeciso", ${ }^{20}$ la última característica como si en ella dependiera su mirada feroz y su carácter violento: producto del mestizaje.

La concepción del mestizaje es un aspecto muy importante tanto desde el estereotipo que los extranjeros tenían como desde los propios conciudadanos, porque, como se sabe, con la organización de los Estados modernos, la construcción de la Nación surgió como una inquietud paralela a este nuevo devenir político, pero que iba más allá. Una de las preocupaciones latente siempre fue la conformación racial de los pueblos, por lo que el mestizaje hacía parte de esa "indecisión" inherente de estos nuevos Estados, bajo el supuesto de que ese mestizaje era el elemento que no permitía el progreso.

Estos intentos por descifrar la composición demográfica de la ciudad eran, en parte, fruto de la necesidad de ordenar una realidad racial que el mestizaje había tornado imprecisa. Sin embargo, y a pesar de la porosidad de las categorías raciales de la época, la mayoría de los viajeros coincidieron en que los sujetos negros constituían el grueso de la población de ciudades como Cartagena. En 1823, el viajero francés Gaspard Mollien afirmó que la mayoría de los habitantes era "hombres de color en su mayor parte marineros o pescadores". ${ }^{21}$ Auguste Le Moyne, que visitó el país cinco años después, afirmó que "la gente de color" era numerosa y que suministraba "el contingente de marineros y de soldados". ${ }^{22}$ Para mediados de siglo, la composición demográfica parecía ser la misma. El diplomático brasileño Miguel María Lisboa comentó que entre los habitantes de la ciudad "predomina la raza mixta de sangre africana". ${ }^{23}$ Y Charles Saffray, aunque no hizo referencia al grueso de la población, indicó que el barrio de la Trinidad "estaba habitado solo por negros, mestizos o indios". ${ }^{24}$ Pero esto no se limitó a lo escrito, también fue constante en las representaciones visuales de los espacios públicos, es decir, que, si bien consideraban que había un predominio de los sujetos negros en la sociedad caribeña, las representaciones de estas escenas fueron muy explicitas en mostrar esta característica, algo que también se puede ver en la imagen 1. En esta representación, Blaney, pretendió ilustrar la cotidianidad de la ciudad enmarcada en las personas de origen africano y en sus "actividades habituales", al mismo tiempo que, el marco de la imagen denota, según el autor, la condición de inferioridad de estos habitantes, en la medida que, sus oficios y su acceso al poder han sido históricamente limitados.

\footnotetext{
${ }^{20}$ Eliseo Reclús, Viaje a la Sierra Nevada de Santa Marta (Bogotá: Ministerio de Educación, 1947), 203.

${ }^{21}$ Gaspard Mollien, Viaje por la República de Colombia en 1823 (Bogotá: Ministerio de Educación, 1944), 16.

${ }^{22}$ Auguste Le Moyne, Viajes y estancias en América del Sur, la Nueva Granada, Santiago de Cuba, Jamaica y el Istmo de Panamá (Bogotá: Ministerio de Educación, 1945), 359. En 1850 el estadista británico Edward Henry Stanley afirmó que dos tercios de la tropa de la ciudad eran negros y que el resto "parecía sangre india en las venas". Stanley, Edward Henry. Six Weeks in South America (London: T. and W. Boone, 1850), 11. La traducción es nuestra.

${ }^{23}$ Miguel María Lisboa, Relación de un viaje a Venezuela, Nueva Granada y Ecuador. (Bogotá: Fondo Cultural Cafetero, 1984), 68.

${ }^{24}$ Charles Saffray, Viaje a Nueva Granada (Bogotá: Ministerio de Educación, 1948), 225.
} 


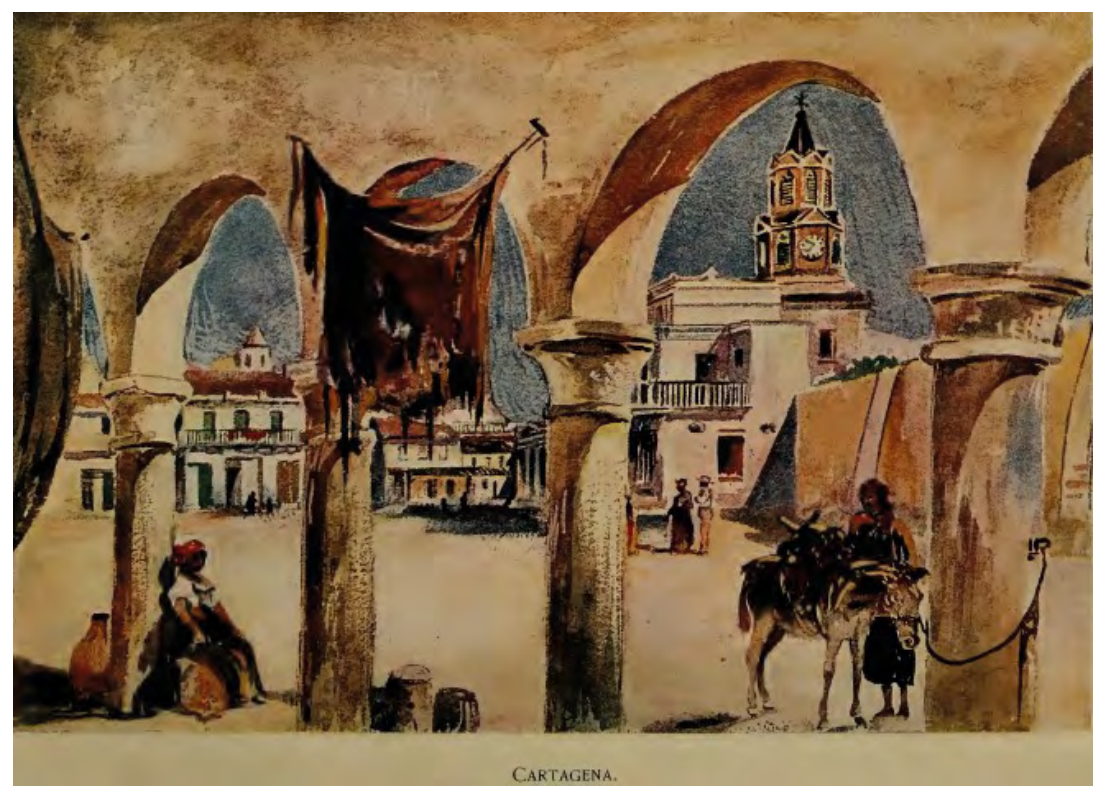

Ilustración 1. Plaza del reloj Cartagena de Indias

Blaney, Henry R. The Golden Caribbean: A Winter Visit to the Republics of Colombia, Costa Rica, Spanish Honduras, Belize and the Spanish Main. (Boston: Lee and Shepard, 1900). Public domain.

Cortesía Hathi Trust Digital Library https://catalog.hathitrust.org/Record/009598842

La presencia de lo afrodescendiente era visible aún en los lugares en los cuales no constituían la mayor parte de la población. El novelista inglés Anthony Trollope comentó que, aunque los "negros de raza pura" no fueran tan abundantes a lo largo y ancho de la Nueva Granada, en ciudades como Santa Marta "los rastros de lo negro, el cabello lanudo y las narices chatas son bastante comunes, siempre mezclados con la sangre india y en buena medida con la sangre española". ${ }^{25}$ Según el geólogo y periodista alemán Julius Fröbel la mayoría de la población local de Chagres en el Istmo de Panamá era de "casta Indo-Hispana", aunque hubiera una población notable de personas de color, en su mayoría provenientes de Curazao y Cartagena. ${ }^{26}$ Aunque reconocieran el extenso mestizaje, era innegable que los viajeros creían en el predominio de los afrodescendientes en las regiones costeras del país.

Estas descripciones, en apariencia neutrales y objetivas, constituían unjuicio de valor.Los viajeros construyeron discursivamentelarealidad racialdel país através deluso decategoríasraciales ydelaincorporación delacomposicióndemográficaensusrelatos. ${ }^{27}$

\footnotetext{
${ }^{25}$ Anthony Trollope,. The West Indies and the Spanish Main. (New York: Harper and Brothers Publishers, 1860), 240. La traducción es nuestra.

${ }^{26}$ Julius Fröbel, Seven Years' Travel in Central America, Northern Mexico, and the Far West of the United States (London: Richard Bentley, 1859), 9.

${ }^{27}$ Melissa Nobles, Shades of Citizenship: Race and the Census in Modern Politics. (Stanford: Stanford University Press, 2000), XI.
} 
En una época marcada por el ascenso del racismo científico sugerir que la mayoría de la población de un lugar era de origen africano equivalía a afirmar que aquel vivía al margen de la vida civilizada. La dicotomía civilización/barbarie era evidente en los relatos, en primer lugar, porque se consideraba que todo lo de origen africano tenía esa connotación y, segundo, por la mancha de la sangre.

Lo anterior obedece a la visión que se tenía de África, la cual estuvo dominada por la expansión de las misiones que trataban de "salvar" las almas de los africanos. En medio de estas acciones se configuró una idea sobre África inmersa en objetivos catequizantes y civilizatorios, los cuales justificaban la "utilidad de la esclavización". Una de las características relevantes durante este período fue la invención del bárbaro, ${ }^{28}$ esto fue una manera de configurar una narrativa para justificar, desde la metrópoli, la exploración del continente africano, mientras capturaban a sus habitantes para ser esclavizados en el Nuevo Mundo. Todo esto se dio bajo la premisa de que Europa era un espacio fundamentalmente diferente y "superior" al resto del mundo, idea que emergió en la Antigua Roma con Plinio el Viejo, quien consideraba que existían razas monstruosas con el fin de ilustrar estereotipos de las sociedades lejanas, como los caníbales que se creía que vivían en África central y otras regiones. ${ }^{29}$ Estos pensamientos se mantuvieron a través de los siglos, en la que una pequeña parte de Europa occidental se impuso al mundo a partir de una exégesis de los valores y de las instituciones necesarias para gestionar el espacio y tiempo. Estas interpretaciones y valores que aplicaban se convirtieron progresivamente en la versión superior de estos, lo que permitió que emergiera Europa como la "culminación" del progreso y la civilización. En ese sentido, Castro-Gómez aportó al conocimiento de la sociedad pre y post-independentista, en lo que es posible ver una marcada dominación política y económica que persistió a través de los supuestos de la supremacía del conocimiento europeo, estos puestos por encima los lugares colonizados; además dicho conocimiento construyó y legitimó los imaginarios y las representaciones que se tenían de las personas que, según la época, eran considerados como inferiores, como parte de las "razas inmaduras". ${ }^{30}$

Como se puede ver en la segunda ilustración esta condición de incivilidad no quedó atrás con el tiempo, todo lo contrario, se mantuvo. Esto se puede analizar a dos niveles, primero la persona sostiene un loro, si bien, este parece ser su oficio, no es fortuita la imagen. Si se revisa las acepciones de la RAE lexicográfico al termino loro, es posible darse cuenta de que se usaba dicha designación para referirse al tono de piel "entre blanco y negro". ${ }^{31}$ La definición que más llama la atención es la de 1611 en la que se puede ver claramente una estrecha relación entre la palabra loro y

\footnotetext{
${ }^{28}$ Cayolla, Sciencia da Colonisação, Lisboa, Typographia da Cooperativa Militar, 99

${ }^{29}$ Peter Burke, "Estereotipos de los otros", Visto y no Visto. El uso de la imagen como documento histórico (Traducción de Teófilo de Lozoya, Barcelona, Crítica, 2005), 159-160.

${ }^{30}$ Santiago Castro-Gómez, La hybris del punto cero: ciencia, raza e ilustración en la Nueva Granada (1750-1816) (Bogotá: Editorial Pontificia Universidad Javeriana, 2010), 38-42.

${ }^{31}$ Consultar el termino en la RAE http://ntlle.rae.es/ntlle. Ahí se podrán encontrar definiciones desde 1495 hasta 1992. Este escrito se limitará a las definiciones de los primeros cuatro siglos.
} 
La imagen de las personas racializadas y la construcción del sujeto negro: el racismo y la...

esclavo, porque lo asemejan a su condición de cautivo, y a su vez, su condición de servidumbre (esto en relación con los papagayos). El otro nivel que se puede analizar son las continuas referencias a los animales considerados como salvajes, tales como el simio o el caimán (ver imagen 3); esto, porque se consideraba que los sujetos negros estaban en capacidad de relacionarse con ellos fácilmente.

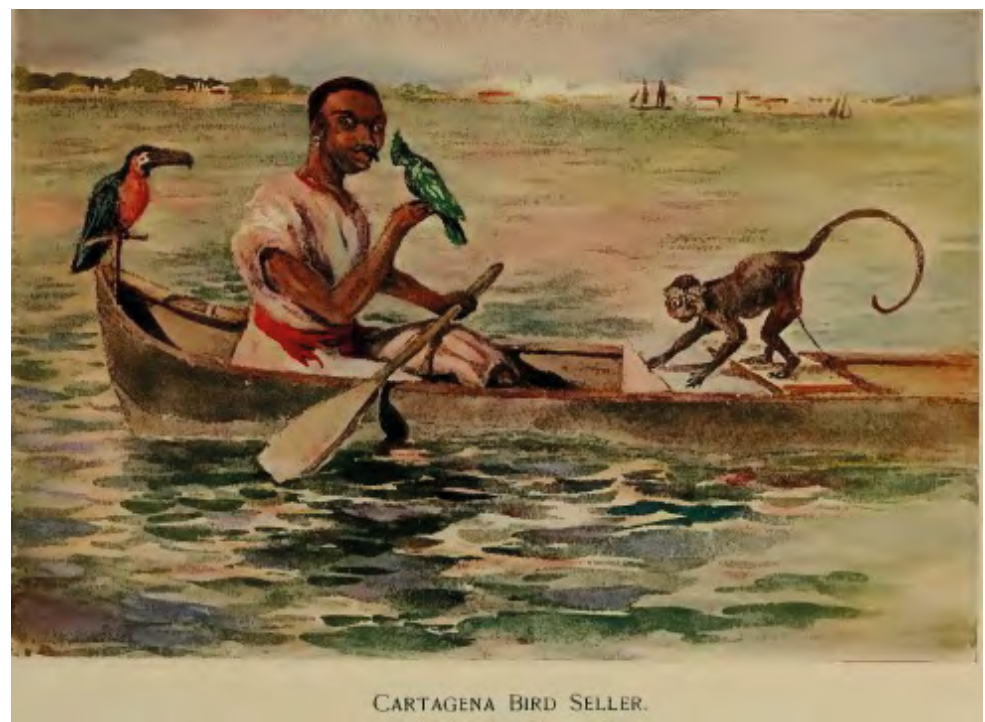

Ilustración 2. Vendedor de pájaros

Blaney, Henry R. The Golden Caribbean: A Winter Visit to the Republics of Colombia, Costa Rica, Spanish Honduras, Belize and the Spanish Main. (Boston: Lee and Shepard, 1900). Public domain. Cortesía Hathi Trust Digital Library https://catalog.hathitrust.org/Record/009598842

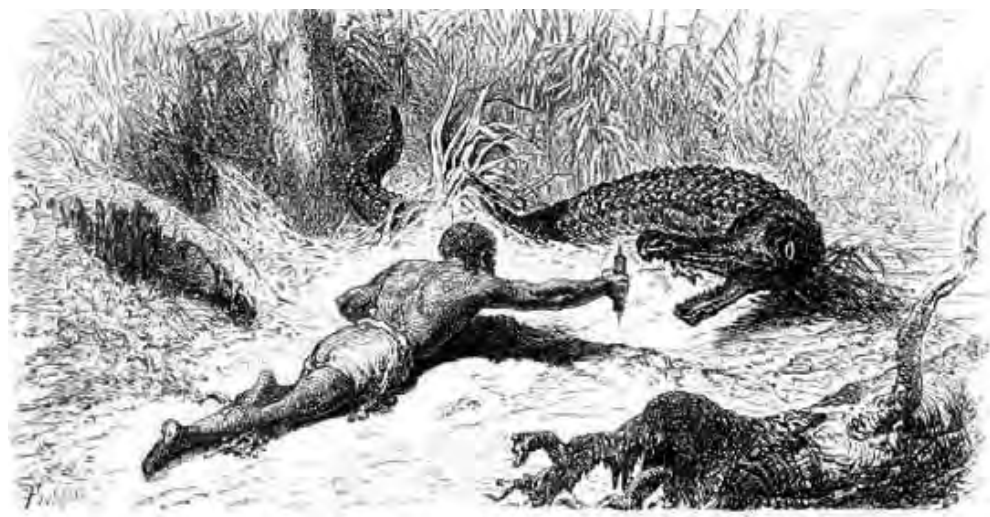

Ilustración 3. Sujeto negro y un caimán.

Saffray, Charles. Voyage à la Nouvelle Grenade. (S. Edi: 1869). Public Domain Mark 1.0 Creative Commons. Cortesía archive.org: https://archive.org/details/VoyageaLaNouvelleGrenade/page/n112/ mode/2up 
En consecuencia, tener personas de origen africano dentro de la población, según este pensamiento, implicaba que el país estaba inmerso en la barbarie, dado que los descendientes de africanos no podían desvincularse de sus antepasados ligados a los esclavizados por ser considerados como viles atendiendo a las circunstancias en las que sus arribaron a tierras americanas. Durante el periodo virreinal, la pureza, el honor y el linaje se convirtieron en los pilares de dicha selección y estratificación social; cuestiones que se mantuvieron más allá incluso con la conformación del Estado-nación durante el siglo XIX. Esto se hace evidente en las descripciones del comerciante bogotano Nicolás Tanco a su llegada a Cartagena en 1851. Para Tanco, el estancamiento de la ciudad estaba directamente relacionado con la presencia abrumadora de personas afrodescendientes:

Dos impresiones principales experimentéal entrar en la ciudad: una de admiración por la hermosa vista que se presenta: otra de pena y de tristeza por la excesiva cantidad de negros. Por todas partes reina la quietud; no hay casi actividad, la población parece muerta [...] La desproporción en que se halla la raza blanca con respecto á la negra fué una de las cosas que más me sorprendieron. Pensar que por cada blanco hay nueve diez negros, es una cosa horrible y desconsoladora ${ }^{32}$

Durante el siglo XIX, intelectuales y políticos del interior andino construyeron una geografía racializada del país donde las tierras bajas del Caribe y el Pacífico eran representadascomolugaresindómitosyproclivesalaspestesyhabitadosensumayoríapor afrodescendientes e indígenas que vivían, según ellos, sumidos en el atraso y la barbarie. ${ }^{33}$ La construcción de estas narrativas (visuales y escritas) articulaban los postulados del determinismo ambiental y el racismo científico, al mismo tiempo que, sirvieron para justificar la hegemonía de la región andina por encima de las periferias de la nación. Eran, por demás, parte de los esfuerzos de las élites del interior por definir los términos y características de la nación en base a nociones geográficas, raciales y civilizatorias. ${ }^{34}$

Los viajeros extranjeros, en particular, insistieron en la precariedad de la vida civilizada en las costas de la Nueva Granada. Por ejemplo, S.S. Hill comentó que entre los habitantes de Cartagena había un desapego por "las delicias inherentes a la civilización": "Niños y jóvenes de raza mixta de ambos sexos, y que en apariencia tendrían entre diez y doce años, andaban desnudos -al igual que las indias del istmo [de Panamá]- no solo por las calles, sino en las tiendas donde la pobreza no podía ser la excusa". ${ }^{35}$ Como se puede ver en la imagen 4 y en la descripción de Hill, la desnudez del sujeto negro fue una constante, tanto que incluso se puede ver reflejada

\footnotetext{
${ }_{32}^{32}$ Nicolás Tanco Armero, Viaje de Nueva Granada a China y de China a Francia (Paris: Imprenta de Simon Raçon y Comp, 1861), 10-11.

${ }_{33}$ Alfonso Múnera, Fronteras imaginadas. La construcción de las razas y de la geografía en el Siglo XIX colombiano (Bogotá: Editorial Planeta, 2005); Nancy Appelbaum, Dos plazas y una nación. Raza y colonización en Riosucio, Caldas, 1846-1948 (Bogotá: ICANH, Uniandes, Universidad del Rosario, 2007).

${ }^{34}$ Muñoz, "Las imágenes", 175.

${ }^{35}$ Hill, S. S. Travels in Peru and Mexico, vol. 2 (London: Spottiswoode and Co., 1860), 144. La traducción es nuestra.
} 
en la Comisión Corográfica (y en la imagen de Saffray), una relación que no obedecía a los mismos parámetros de los anteriores viajeros, pero sí a una concepción de civilidad que fue determinante para que, los sujetos negros, fueran descritos como vagos y borrachos, dos características que acompañaron las descripciones de las personas racializadas, en la medida que esto justificaba la percepción de barbarie que se tenía de ellos.

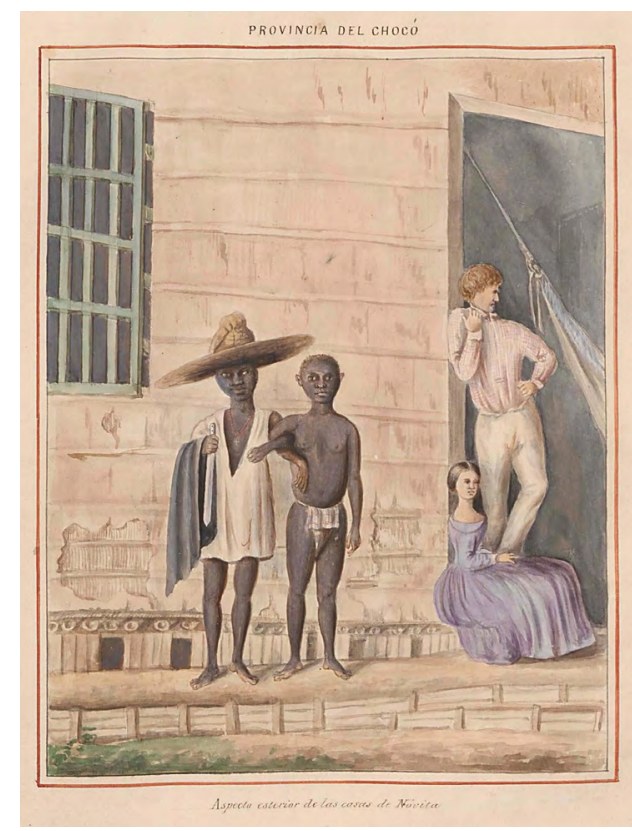

Ilustración 4. Pareja de personas de origen africano

Provincia del Chocó.

Manuel María Paz, Comisión Corográfica, 1853 Imagen cortesía de la Cortesía Biblioteca Nacional de Colombia

Además de la desnudez, hubo otros temas que fueron recurrentes en la construcción de estas narrativas visuales y escritas hechas por los viajeros, como, por ejemplo, sus capacidades intelectuales. Santiago Pérez durante su viaje a la Provincia del Chocó para la Comisión corográfica, narró que lo único que podía ver era "la salvaje estupidez de la raza negra, su insolencia bozal, su espantosa desidia, su escandaloso cinismo". ${ }^{36}$ Descripciones, por demás, muy explícitas y detalladas a la hora de desdeñar sobre las condiciones de los sujetos negros, al mismo tiempo que, no desmarcan su herencia racial y su origen africano al momento de detallarlos, es decir, que muy a pesar de que la esclavitud se había abolido y que las condiciones, en teoría, habían cambiado, su condición de sirviente y esclavo seguían vigentes en el imaginario de la población y, por tanto, era necesario reforzarlo con estos detallados informes que eran publicados en medios nacionales e internacionales.

${ }^{36}$ Santiago Pérez, Apuntes de viaje. Segundo artículo. El Neogranadino, Dic. 1, 1853, 441. 
Al igual que los encargados de la Comisión Corográfica, el ingeniero inglés Lionel Gisborne también hizo referencia a la condición del sujeto negro en los años de la abolición de la esclavitud. Gisborne visitó el Darién entre 1850 y 1852, justo cuando se firmó y entró en vigor la abolición y la extensión de la ciudadanía a los libertos en la Nueva Granada. Tras un breve tránsito por Panamá y Cartagena, escribió sus impresiones sobre los efectos de aquel suceso. Gisborne desconfiaba de la capacidad de las personas negras para amoldarse a la civilización. Para él no había duda: "de que a medida que se incrementa la población negra el progreso, tanto moral como intelectual, cesa, como en Haití, donde la semi-barbarie se abre paso". ${ }^{37}$ Sugería crear colonias donde los exesclavos y sus descendientes pudieran desarrollarse sin perturbar a las otras razas. "Si la filantropía demanda la distribución equitativa de la civilización", decía, "también debería protegerse a quienes por voluntad propia la han difundido en regiones donde existía el barbarismo hasta hace pocos años". ${ }^{38}$

El político e intelectual liberal José María Samper era más optimista. En su paso por Cartagena afirmó que la redención del país sería posible a través del fomento de la inmigración europea y del mestizaje. ${ }^{39}$ El blanqueamiento progresivamente a la nación y la introducción del espíritu civilizador europeo bastarían para colocar al país dentro de la senda del progreso:

Cartagena tiene muchos elementos de prosperidad, y puede ser grande por la agricultura interior y por el comercio de importación y exportación. Pero para prepararse un porvenir digno de su posición, necesita abrir paso á los vapores entre su puerto y el río Magdalena, restableciendo su canal casi obstruido, ó bien fundar la comunicación terrestre por medio de un ferrocarril ó una buena vía carretera. Lo que ese hermoso mundo necesita es contacto con las demás sociedades, con todas las razas, con la civilización exterior en todo su desarrollo. Así, puede decirse que la obra compleja de civilizar a Colombia está resumida en esta frase: comunicarla con el mundo, lanzarla en el movimiento universal. ${ }^{40}$

Como se mencionó anteriormente, las representaciones del sujeto negro en la cultura letrada del siglo XIX no solo sirvieron para reforzar estereotipos sobre los individuos, sino que ayudaron a la construcción de geografías racializadas. En buena medida, esto obedece a que los cuerpos racializados eran representados como parte integral de los paisajes naturales. El ambiente, indómito y malsano, era equiparable al fenotipo y las características conductuales de los individuos, particularmente, aquellos de origen africano. ${ }^{41}$ Carl August Gosselman, un oficial de la marina sueca visitó el país entre 1825 y 1826 . Durante su estadía describió en estos términos la vida

\footnotetext{
${ }^{37}$ Lionel Gisborne, The Isthmus of Darien in 1852. Journal of the Expedition of Inquiry for the Junction of the Atlantic and Pacific Oceans. With Four Maps (London: Saunders and Stanford, 1853), p. 126. La traducción es nuestra

${ }^{38}$ Gisborne, 124.

${ }^{39}$ Múnera, Fronteras.

40 José María Samper, Viajes de un colombiano en Europa, en: Deavila, Orlando y Guerrero, Lorena (Compiladores), Cartagena vista por los viajeros, Siglo XVIII-XX (Cartagena: Universidad de Cartagena Alcaldía de Cartagena, 2011): 218.

${ }^{41}$ Sheller, Consuming the Caribbean, 62.
} 
La imagen de las personas racializadas y la construcción del sujeto negro: el racismo y la...

cotidiana de las calles de Cartagena:

La mayoría de las calles no están empedradas sino llenas de arena, y en distintos lugares pueden verse grupos de negritos desnudos dando volteretas, muchas veces en compañia de un mico, el que solamente se distingue de ellos por sus saltos más altos y sus movimientos más ágiles. Todo el espectáculo se acompaña de una música que para quien no está acostumbrado a oír, resulta una variante del parloteo de los papagayos sentados en las puertas y en los balcones; es decir, el idioma del pueblo inferior. Aunque el español es tan bello si está bien hablado, cuando proviene de la boca del negro o del indígena, resulta para el extranjero de una naturaleza inentendible, así como los gritos de los pájaros. ${ }^{42}$

Como se pudo ver en la segunda imagen, asociar lo afrodescendiente con homínidos no era una rareza. Algo similar hizo el venezolano Ramón Páez cuando comparó a un mono tití que había comprado en las costas de Cartagena con un africano debido, según él, a la "aparente" similitud de sus rostros. ${ }^{43}$

Por otro lado, además de ser racializados, los cuerpos de las mujeres afrodescendientes eran sexualizados. Sus atributos físicos eran asociados a lo racial y sus calidades estéticas eran sometidas a escrutinio. La sexualización era una forma de procesar y controlar lo afrodescendiente y convertirlo en un objeto etnoerótico, que, aunque era visto como parte de la naturaleza humana, era concebido como potencialmente transgresor y al margen de las normas culturales establecidas. ${ }^{44}$ Gaspard Mollien describió con detalle la apariencia física de las "mujeres de color" en Cartagena, no sin considerar los efectos del mestizaje en sus cualidades estéticas:

Las mujeres de color, si son hijas de negras y de blancos son altas y tienen un aspecto mucho más agradable que el de nuestras mulatas de las Antillas, que por lo general son demasiado gruesas; cuando son hijas de indias y de negros, tienen facciones más delicadas y más expresión en la fisonomía. Si por una parte las razas en los trópicos se debilitan a medida que se van haciendo más blancas, por otra se embellecen; esta es la razón por la cual todas las mulatas son inferiores en belleza a las mujeres blancas, y desmerecen desde este punto de vista cuando se las ve juntas ${ }^{45}$

Esto no era nada nuevo. Desde los tiempos de la esclavitud el poder colonial europeo configuró el cuerpo de las mujeres negras como un objeto de consumo. Se asumía que toda mujer que desempeñara labores manuales fuera libre o no, debía estar en disposición de satisfacer las necesidades sexuales de los blancos. Las mujeres esclavizadas, por demás, tenían a su cargo la reproducción de la fuerza de trabajo. La naturalización de la explotación de los cuerpos llevó a la elaboración de representaciones

\footnotetext{
${ }^{42}$ Carl August Gosselman, Viaje por Colombia. 1825 y 1826 (Bogotá: Banco de la República, 1981), 34-35. El énfasis es nuestro.

${ }^{43}$ Páez, Ramón. Travels and Adventures in South and Central America. With Life in the Llanos of Venezuela (Hartford: T. Belknap, 1873), 323. La traducción es nuestra.

${ }^{44}$ Sheller, Citizenship from Below, 106.

${ }^{45}$ Mollien, Viaje por la República, 89-90.
} 
que sobresexualizaban los atributos físicos de la mujer afrodescendiente. Estos se hicieron extensivos a las mujeres mulatas, cuyos cuerpos fueron exotizados, aunque denotados como estéticamente inferiores a los cuerpos de las mujeres blancas. ${ }^{46}$

Charles Saffray no ahondó en los detalles sobre las características fenotípicas de las mujeres afrodescendientes, pero sí dedicó algunos pasajes a describir sus atuendos y la exposición de sus atributos físicos:

El traje de las mujeres del pueblo, en Cartagena consiste en un jubón corto de sarga, de indiana o de muselina, ajustado por un cinturón de lana de vivos colores; el busto no está cubierto más que por la camisa, muy escotada y guarnecida de encaje, y los brazos se dejan desnudos. Para salir a la calle se ponen un pequeño chal de algodón, de lana o de seda, el cual cruzan sobre el pecho, dejando las extremidades pendientes a la espalda. ${ }^{47}$

Al igual que otros viajeros, José María Samper articuló sus impresiones sobre el cuerpo racializado con el paisaje que le rodeaba. En este caso, asoció la apariencia de la mujer "proletaria", en clara alusión a la mujer afrodescendiente, con el deterioro físico de la Cartagena de la segunda mitad del siglo XIX y con las alimañas que pululaban entre las ruinas:

Las señoras son en general muy bellas, espirituales, expansivas y alegres, y reúnen a la elegancia o la gentileza de las formas una gracia en el decir, en la mirada y la sonrisa, verdaderamente encantadora. Al contrario, las pobres mujeres de la clase proletaria (quizás deteriorada la raza por la miseria y la inacción), son de una fealdad dolorosa: flacas, largas, sombrías, pálidas como espectros, lúgubres como las sombras errantes en medio de las tumbas... ¿Cómo explicar esa contradicción o ese contraste? Yo podría determinar las causas, pero me contentaré con hacer una reflexión. Cartagena es una gran ruina, es una tumba inmensa, y entre las ruinas y las tumbas se encuentran siempre, lo mismo el hermoso lirio lleno de perfume y misterio y el blanco alelí de las murallas, que el lagarto feo y descarnado vagando por entre los pedriscos y los escombros donde vegeta la hiedra. ${ }^{48}$

En este texto, Samper convierte el cuerpo de la mujer afrodescendiente en una representación del momento crítico que experimentaba la ciudad en ese entonces. En pocas palabras, sus cuerpos fueron configurados como repositorios de la barbarie - y, en consecuencia, de la ausencia de civilización — que a consideración de estos viajeros reinaba en los territorios periféricos del país.

\footnotetext{
${ }^{46}$ Kempadoo, Kamala (Editor). Sun, Sex and Gold. Tourism and Sex Work in the Caribbean. (Oxford: Rowman and Littlefield. 1999), pp. 4-9.

${ }^{47}$ Saffray, Viaje a la Nueva, p. 27.

${ }^{48}$ Samper, Viajes de un colombiano, p. 217.
} 


\section{La agencia de los sujetos afrodescendiente en la deconstrucción de la imagen y las jerarquías}

Como explica Sheller, la construcción del "otro" como un ser inferior, racializado o sexualizado, se dio a través de "encuentros corporizados", esto es, a través de la interacción directa entre los cuerpos del visitante y el nativo. Aunque los estereotipos estuvieran determinados por representaciones históricas sobre la negrura en Occidente, estas "gramáticas de la diferencia" también eran construidas a través del acto de la interacción y la observación. Y, a pesar de la asimetría del "encuentro corporizado" y del poder que el viajero imprimió en la construcción de sus narrativas visuales y escritas, hubo instantes del relato/discurso que permiten advertir cómo los nativos desestabilizan el encuentro. Es decir, hay fragmentos dentro de la literatura de viajeros permiten apreciar cómo los locales "respondían a la mirada, la apropiaban y desestabilizaban su poder". ${ }^{49}$ En algunos momentos, los locales se rehusaban a ser partícipes de su propia subordinación; a través de gestos, posturas o contestaciones administraban el "encuentro corporizado" y rompían el equilibrio dictado por la etiqueta racial de la época. El viajero francés Gaspard Mollien, por ejemplo, se sintió perturbado por la actitud altiva de los sujetos negros dedicados a las labores del mar, una

industria con frecuencia elogiada y casi siempre bien pagada [que] ha desarrollado en esa gente de color un orgullo que a veces resulta molesto. Su vehemencia y su petulancia contrastan con la indolencia y con el buen carácter de los hombres que llaman blancos, de modo que, a pesar de su pereza, parecen activos y laboriosos..$^{50}$

Los viajeros provenientes de Europa, o del interior andino, esperaban que la interacción fuera estrictamente vertical y que los afrodescendientes actuaran con respeto y deferencia hacia ellos. Como anotó Charles Saffray, "se obtiene cuanto se quiere de los negros si se halaga su amor propio, dándoles además de vez en cuando una copita de ron". ${ }^{51}$ No obstante, el mismo Saffray se vio obligado a ceder ante la insistencia de un habitante del barrio Getsemaní cuando este le invitó a una fiesta que tenía lugar en el barrio: "Movido en parte por la curiosidad, y acaso también porque no osaba rehusar la invitación de aquel robusto negro, que llevaba pendiente del cinto un largo machete, del cual se sirven allí para cortar la caña de azúcar, cuando no para sus pendencias, acabé por aceptar el ofrecimiento", ${ }^{52}$ comentó.

En algunas ocasiones, los locales administraron los términos del "encuentro corporizado" a su conveniencia. Franco, un colaborador del diario "El Anotador" de Bogotá, recordaba como a su llegada al puerto de Cartagena en 1861 debió presenciar la actitud "insolente" de los trabajadores negros:

\footnotetext{
${ }^{49}$ Sheller, Citizenship, 212. La traducción es nuestra.

${ }^{50}$ Mollien, Viaje por la República, 89. El énfasis es nuestro.

${ }^{51}$ Saffray, Viajes de un colombiano, 31.

${ }^{52}$ Saffray, 26.
} 
[...] venía a recoger los pasajeros y sus equipajes una turba de negros medios desnudos, de lenguaje soez e insolente, infelices lisiados, la mayor parte de enfermedad repugnante, cuya presencia indecorosa causaba la risa burlona de unos, el asombro de otros y el rubor de muchos. Los cargadores de pasajeros venían con sillas de mano, que suspendían con el brazo tendido hacia arriba, para defenderse de la ola. En la silla se sentaba el pasajero, confiado en la fuerza y en la maña de los conductores, lo que no impedía ninguna vez que la ola lo mojara. Y cuando esta era muy fuerte y los cargadores quedaban sumergidos por ella, luego que pasaba, dirigían al infortunado viajero frases como esta: "blanco si no sabe nará agárrese" - "Tiene usted que pagar doble o sino se moja". Y el pasajero se agarraba fuertemente de los brazos de la silla, y si no sabe nará veía llegado sus últimos momentos y ofrecía lo que le pedían. ${ }^{53}$

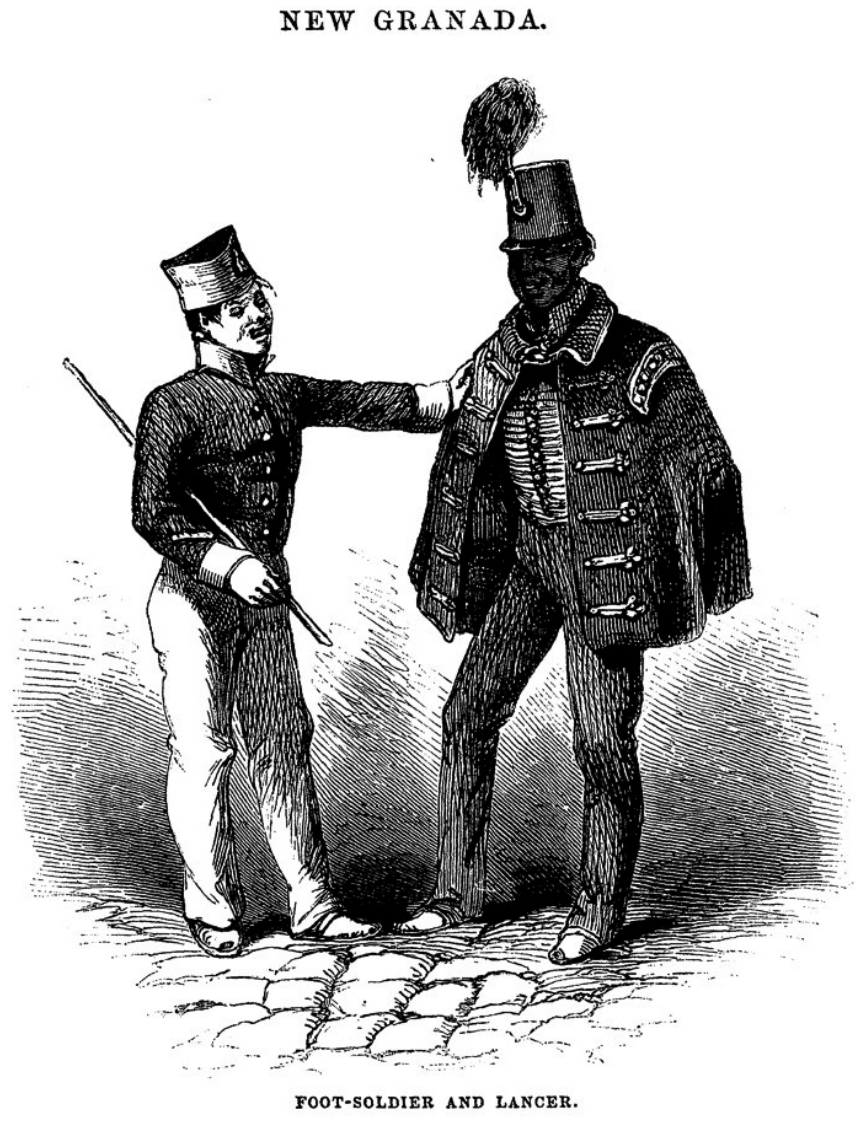

Ilustración 5. Soldado y lancero en la calle

Holton, Isaac F. New Granada: twenty months in the Andes. (New York: Harper \& brothers, 1857).

Public domain. Cortesía Hathi Trust Digital Library

${ }^{53}$ Franco, "Cartagena, ayer y hoy", en: Deavila, Orlando y Guerrero, Lorena (Compiladores), Cartagena vista, 252. 
Franco comentó que la situación era aún más molesta para las mujeres, para "una mujer delicada sobre todo, pues para todos cualquiera que fuera su posición social, tenían los negros una chanza de mal gusto, una observación picante". ${ }^{44}$ Añadió, además, que habían algunos que "cobraban el servicio que no habían prestado, en lenguaje tan grosero y amenazante, que no había más remedio que pagar, sobre todo si para colmo de desgracias, acompañaba uno a una señora, pues el cuadro de aquellos hombres con sus pocos vestidos mojados y pegados al cuerpo y su lenguaje grosero eran cosas de evitar". ${ }^{55}$

Al analizar los momentos de agencia e insubordinación de los sujetos negros es posible advertir que, a pesar de la estigmatización visual y escrita, estos habían encontrado en el mar un espacio donde podían desestabilizar la verticalidad de los "encuentros corporizados". Su experiencia les daba un margen de ventaja que no desperdiciaban para sacar partido de la interacción con los visitantes. ${ }^{56}$ Lejos de ocupar un lugar de total subordinación, los hombres de mar (y río) gozaban de un oficio que les brindaba independencia y algún capital económico, lo que les permitía negociar a su conveniencia los términos del servicio prestado a los viajeros. Por otro lado, y a diferencia del nativo promedio, estos gozaban de mayores posibilidades de movilidad, y, por ende, de acceso a bienes y capital cultural. El estatus del cual estos gozaban queda en evidencia en el relato de Carl August Gosselman, un oficial de la Marina Real de Suecia, quien, a pesar de su rango y procedencia, no pudo evadir la altivez de los sujetos negros dedicados a la mar. Este suceso narrado por Gosselman también pone en evidencia los efectos inmediatos del establecimiento de la república y de sus nuevos valores:

El práctico tenía la costumbre, un tanto extraña, de subirse al puesto de vigía de la proa y, desde allí gritar con todas sus fuerzas las órdenes. Esto lo hacía semidescubierto y como lo consideramos inconveniente le pedimos que se viniera a la popa y permaneciera en su puesto. Esta solicitud posiblemente le pareció que rompía las reglas de la República, pues bajó, tomó su pequeño maletín, una calabaza grande que había llevado bajo el brazo con el mismo celo con que las mujeres llevan sus adornos corrió hasta la parte posterior del velero y en un instante volvió totalmente cambiado de ropas, o sea con una buena y limpia camisa y pantalones, en reemplazo de los gruesos y sucios de lino que antes usaba.

En un comienzo se hizo difícil entender la relación existente entre esta verdadera metamorfosis y la orden de venirse a la popa, pero pronto nos aclaró todo cuando con aire arrogante y (p. 29) andar orgulloso nos dijo: "Soy hombre libre y caballero, como ustedes; e inmediatamente se fue, con aire de vencedor, a ocupar su sitio anterior, en el puesto de vigía de proa. Él consideraba que nosotros nos habíamos equivocado sobre su real valor, pareciéndole indiscutible ahora, con su cambio de vestimentas. ${ }^{57}$

\footnotetext{
${ }^{54}$ Franco 253.

${ }^{55}$ Franco 253.

${ }^{56}$ Villamizar y Riaño Pradilla. Esclavos, negros libres, 141-256.

${ }^{57}$ Gosselman, Viaje por Colombia, 30.
} 
No solo la interacción cotidiana o los "encuentros corporizados" desafiaban los marcos de interpretación de los viajeros. Varios viajeros vieron con desconcierto los cambios políticos que experimentó la Nueva Granada tras la independencia y cómo los sujetos negros, lejos de ser seres subordinados, actuaban como ciudadanos plenos hasta el punto de ocupar prominentes cargos públicos. Algunos viajeros veían con asombro y sospecha el alcance de estas transformaciones que aún eran inconcebibles en el Atlántico Norte. ${ }^{58}$

También se debe mencionar que otros destacaban con entusiasmo los primeros avances de la república en materia de igualdad racial. Tal era el caso del periodista y militar británico Francis Hall, quien celebró en estos términos la legislación igualitaria implementada durante los primeros años de la república:

Las leyes de la república no ven más que ciudadanos indistintamente de la diferencia de clase de sus habitantes, cualquiera que sea su origen o complexión. La justicia de esta política ha sido recompensada por los esfuerzos de la gente de color y sus auxilios a la independencia del país. Ellos han sido los más firmes partidarios, y Colombia reconoce entre los mejores y más valientes oficiales a aquellos que el orgullo y la tiranía española no creía merecedores de sentarlos a la mesa de un hombre blanco ${ }^{59}$

En consonancia con lo anterior, es importante tener en cuenta que Hall era cercano a Jeremy Bentham, y, por ende, simpatizaba con los postulados de la filosofía liberal y los resultados de su implementación en las Américas. Otros, por el contrario, eran menos entusiastas. ${ }^{60}$ Tal era el caso de Ventura Aguilar, quien comentó que "una exagerada democracia" y la sucesión de revoluciones habían permitido "la admisión en los puestos gubernamentales de individuos de la raza etiópica" ${ }^{61}$ Cuando estuvo de paso por Cartagena en la década de los 80 , notó que el gobernador y el alcalde "honrosos individuos de la raza etiópica [...] desplegaban con todos gran arrogancia de mando, que seguramente hubiera dejado algo atrás á los virreyes españoles, los de la ominosa y tiránica dominación, cuya sacudida había costado tantos mártires". ${ }^{62} \mathrm{El}$ texto de Aguilar pone en evidencia que los "encuentros corporizados" no se limitaron a la interacción con individuos anónimos en las calles, sino que también ocurría con algunos afrodescendientes que habían alcanzado lugares de prominencia pública. No obstante, los viajeros todavía repudiaban la actitud de estos líderes. A pesar de los cargos prominentes que ocupaban, ellos esperaban la deferencia que ellos pensaban era característica de los sujetos negros. Cuando estos actuaban por fuera de los marcos

\footnotetext{
${ }^{58}$ James Sanders, The Vanguard of the Atlantic World. Creating Modernity, Nation, and Democracy in Nineteenth-Century Latin America (Durham: Duke University Press, 2014).

${ }^{59}$ Hall, Francis. Colombia: Its Present State, in Respect of Climate, Soil, Productions, Population, Government, Arts, Literature, Manners, Education, and Inducement to Emigration (Philadelphia: A. Small, E. Parker, E. Littell, and Marot \& Walter, 1825), p. 19. La traducción es nuestra.

${ }^{60}$ Bentham a su vez mantenía una relación epistolar con Simón Bolívar. Ver: McKennan, Theodora, "Jeremy Bentham and the Colombian Liberators," The Americas, 34, 4 (1978): 460-475.

${ }^{61}$ Ventura Aguilar, Otros horizontes (Montevideo: Imprenta a vapor La Colonia Española, 1886), 76.

${ }^{62}$ Aguilar 84.
} 
de representación eran descalificados como insubordinados, y en este caso, como arrogantes.

Lo anterior estaba ligado con el pensamiento virreinal en el que la "pureza de la sangre" debía seguir vigente a la hora de ocupar ciertos lugares en la sociedad, ya fueran cargos administrativos, clericales o en el acceso a algunos privilegios. Como se sabe, la limpieza de sangre operó para excluir a los judíos y moros recientemente convertidos, también para los considerados sin honor como los descendientes de africanos. Para evitar la participación de este tipo de personas, se implementaron rigurosos estudios para investigar la ascendencia genealogía de cada persona que pretendía acceder a puestos políticos o religiosos, lo que impedía que, las personas manchadas con algunas de estas características pudiesen escurrirse en ciertas esferas de la sociedad virreinal. Todas estas prohibiciones afectaron a los sujetos negros, en la medida que, como ya se mencionó, tenían el estigma de descender de personas esclavizadas, por tanto, su honorabilidad y pureza no podía ser garantizada. Sin embargo, el establecimiento de la república hizo que estas medidas perdieran efectos legales.

El ingeniero Lionel Gisborne ahondó en los efectos logrados por las políticas de igualdad y justicia racial implementadas en la Nueva Granada y otros países del Caribe durante la primera mitad del siglo XIX. Decía que la república había sido fiel a sus principios, y que "todos los colores eran admitidos en todas las oficinas públicas". ${ }^{63}$ Para Gisborne esto era motivo de preocupación debido a la aparente predisposición de los afrodescendientes al radicalismo y la subversión. Ellos han sufrido la "autocracia", decía Gisborne:

por lo tanto, son naturalmente demócratas [...] no tienen mucha para perder, pero si mucho por ganar a través de la subversión. No creo que nadie pueda afirmar que en Haití o en Jamaica la introducción de sangre negra a las asambleas legislativas y a posiciones de confianza haya avanzado la causa del progreso. Ciertamente [la república] ha corregido el monopolio del cual disfrutaba la raza blanca. ¿Pero con qué resultados? Sacó del país a las únicas personas cuyos intereses eran el orden, el progreso y el desarrollo intelectual. ${ }^{64}$

Para él, había que esperar el paso de varias generaciones para que los afrodescendientes se convirtieran en conservadores y comenzaran a trabajar por el bien común. Mientras tanto, según él, terminarían por conducir sus sociedades al atraso. De ahí su insistencia en la construcción de colonias donde los sujetos negros pudieran prosperar de manera independiente sin afectar el progreso de las personas blancas. Aunque creía que era innegable que "por cultivación los negros podían ser elevados en la escala social en dos o tres generaciones", temía que "su contacto con los blancos retrasará el progreso y frenará el desarrollo de las energías que siempre originan las razas más educadas. En el mejor de los casos, él [el negro] es un imitador, sigue la pista trazada, pero en la mayoría de los casos la obstruya con su presencia" ${ }^{65}$ En su postura,

\footnotetext{
${ }^{63}$ Gisborne, The Isthmus of Darien, 87.

${ }^{64}$ Gisborne, 123-124.

${ }^{65}$ Gisborne, 123.
} 
Gisborne no solamente parecía ser partidario del conservatismo, sino que compartía los postulados del racismo científico. Para él, la ciencia había demostrado que "el cerebro de un negro adulto no es más grande que el de un niño blanco ordinario" . ${ }^{66}$ Sin embargo, creía que la educación y el entrenamiento podía ayudar al "desarrollo mental y muscular", aunque tales cambios tomarían dos o tres generaciones.

Lo anotado por Gisborne, y los demás viajeros, demuestra que la blanquitud era el patrón para definir los límites del progreso, la civilización o la inteligencia. Se era civilizado, por ejemplo, en la medida en que se adoptaban costumbres y formas asociadas a la cultura europea y/o occidental. La negrura, por el contrario, fue construida, a través de la narrativas visuales y escritas, como el extremo opuesto. Esta dicotomía no solo sirvió para construir representaciones sobre lo afrodescendiente o lo africano, sino que, también presentó como una oportunidad para definir la identidad de lo blanco y los valores asociados al mismo. Es decir, la blanquitud se construyó en oposición a la negrura.

A pesar de la proximidad de los “encuentros corporizados" y de las aperturas que había logrado la república — y que colocaba a los afrodescendientes en espacios de socialización otrora reservados para los blancos-, los viajeros procuraban guardar distancia con los locales y mantener la jerarquía que dictaban las convenciones de la época. Por este mismo motivo, redujeron al "otro" racializado a un objeto de observación y, rara vez, interactuaron con él en condiciones de igualdad; ni siquiera cuando les encontraban ocupando cargos de administración pública. Los afrolatinoamericanos constituían un desafío a las ideologías raciales de la época. Por más que intentaran representarlos como seres salvajes e indómitos, estos habían logrado un lugar en las sociedades nacionales y habían adoptado muchas de las formas y costumbres características de Occidente. La imposibilidad de ubicarlos, física o discursivamente al margen de las nuevas repúblicas, llevó a insistir en las diferencias raciales para justificar sistemas de inequidad, discriminación y segregación. ${ }^{67}$ De esta forma, los ubicaron de nuevo dentro de la matriz africana, considerada como el arquetipo de lo salvaje y lo opuesto a Occidente. Nótese que Ventura Aguilar denominó a los líderes políticos afrodescendientes que encontró a su paso por Cartagena como miembros "de la raza etiópica". Ese énfasis en la diferencia racial y biológica, y los esfuerzos por trazar una línea entre lo blanco y lo negro, definidos como los extremos opuestos de la dicotomía civilización-barbarie, terminaron dando lugar al avance del racismo científico durante el siglo XIX. ${ }^{68}$ La literatura de viajeros contribuyó a ese propósito.

\section{Conclusiones}

Como se ha podido ver a través del texto, el sujeto negro fue visto como la perversión de la sociedad colombiana del siglo XIX. Su existencia estuvo marcada por la concepción de atraso, la incivilización y la barbarie, aspectos que iban en

\footnotetext{
${ }^{66}$ Gisborne, 125.

${ }^{67}$ Sheller, Consuming, 109-111.

${ }^{68}$ Peter Wade, Raza y etnicidad en América Latina (Quito: Ediciones Abya Yala, 2000), 17-18.
} 
contravía al pensamiento industrial y moderno que dictaba que algunas personas poseían más capacidades que otras y, por tanto, eran más aptas para el avance en la construcción de la Nación. De ahí que sea recurrente las menciones a los cuerpos racializados como parte del rezago y retroceso de la sociedad. Al mismo tiempo, se observa que la conceptualización del sujeto negro como salvaje e incivilizado ha sido de larga duración, porque esta se ha concebido desde África a partir del inicio de la esclavización de las personas de origen africano y esto se pudo llevar a cabo bajo el precepto dualismo civilización y barbarie, y ambos, como quedó evidenciado, se mantuvieron hasta mucho después del siglo XIX gracias a los pensamientos racistas de la época en la que se cimentó el racismo científico.

El medio ambiente y el calor eran tomados como los elementos que influían en la creación de las bestias que se asemejaban a obras diabólicas. En líneas generales, el africano fue descrito casi como un animal salvaje, caníbal y sin cultura, en oposición a la cultura católica de los "blancos civilizados", de ahí que la esclavización y opresión de la población africana se justificó constantemente durante varios siglos, $y$, por ende, fue el escenario perfecto para ejercer poder sobre los cuerpos esclavizados.

El poder y la opresión ejercida sobre los cuerpos africanos no es un tema reciente. Como bien se sabe, su historia está permeada por la esclavitud que, si bien es cierto, fue abolida hace varios siglos, el estigma ha persistido y ha sido una carga para los afrodescendientes en la medida que esa herencia no se ha olvidado, menos en sociedades que han perpetuado la jerarquía socio-racial en la conformación de los estados nacionales.

Aquí se expusieron algunas imágenes que marcaron la imposición de lo visual para que en otras latitudes como en Europa y EEUU se pudieran ver la necesidad de civilizar esa población. Es decir, estas imágenes y estas descripciones no fueron inocuas y sin propósito alguno, sino todo lo contrario, estas imágenes marcaron el devenir del interés con (re)descubrir América y tener acceso a sus recursos naturales, todo, basado en la concepción del atraso, la barbaridad y el salvajismo de la población que ahí se encontraba.

Aunque ciertamente estas representaciones, que construyeron la imagen del sujeto negro como inferior y ajeno a los rigores de la vida civilizada, sirvieron para crear una nueva forma de dominación colonial entre Europa y América, tampoco estuvieron exentas de contestación cuando los marcos de interpretación de los viajeros se vieron desafiados. A través de los "encuentros corporizados" o de la participación en la vida pública del país, los sujetos negros pusieron en entredicho la jerarquía socio-racial y los postulados del racismo científico que naturalizaban su supuesta inferioridad. Aunque los viajeros intentaron estabilizar la imagen de este a través de sus relatos, no lograron silenciar los episodios en los cuales la agencia de estos y su resistencia cotidiana en contra del racismo quedaba en evidencia. A pesar de la persistencia de modos de representación racistas y/o supremacistas, la abolición del sistema de castas y la igualdad jurídica inauguradas por la república crearon un nuevo escenario que le permitía a los sujetos negros negociar su lugar en la sociedad. 
Como se ha visto, los hombres dedicados a las faenas del mar tomaron partido de su experticia y del capital social, económico y cultural adquirido en su profesión, para establecer los términos de su interacción con los viajeros provenientes de Europa o del interior andino. Así mismo, los viajeros anotaron con desconcierto cómo dichos afrodescendientes ocupaban lugares de prominencia pública y eran parte activa de la vida política local. Todo esto constituye un ejemplo de cómo los sujetos negros fueron capaces de desafiar los límites trazados por una jerarquía socio-racial que todavía imperaba en Occidente, pero que, en Colombia, estaba condicionada o relativizada por las aperturas logradas con la república.

Para llegar a estas conclusiones fue necesario abordar la literatura de viajeros desde una perspectiva metodológica que permitiera interrogar los silencios y los sesgos racistas que los autores imprimieron en sus textos y hacer énfasis en la lectura de los instantes en los cuales lo nativos actuaron en contravía de los preconceptos y las jerarquías socio-raciales de la época. Aunque no fuera su intención primaria, los viajeros pusieron en evidencia tanto los episodios de resistencia cotidiana en contra del racismo y los logros en materia de igualdad racial de la república.

\section{Bibliografía}

\section{Fuentes secundarias}

\section{Libros}

Aguilar, Ventura. Otros horizontes. Montevideo: Imprenta a vapor La Colonia Española, 1886.

Appelbaum, Nancy. Dos plazas y una nación. Raza y colonización en Riosucio, Caldas, 1846-1948. Bogotá: ICANH, Uniandes, Universidad del Rosario. 2007.

Blaney, Henry R. The Golden Caribbean: A Winter Visit to the Republics of Colombia, Costa Rica, Spanish Honduras, Belize and the Spanish Main. Boston: Lee and Shepard, 1900.

Castro-Gómez, Santiago. La hybris del punto cero: ciencia, raza e ilustración en la Nueva Granada (1750-1816), Bogotá: Editorial Pontificia Universidad Javeriana, 2010.

Cayolla, L. Sciencia da Colonisação., Lisboa: Typographia da Cooperativa Militar, 1912.

Deavila, Orlando y Guerrero, Lorena (Compiladores), Cartagena vista por los viajeros, Siglo XVIII-XX. Cartagena: Universidad de Cartagena - Alcaldía de Cartagena, 2011. 
La imagen de las personas racializadas y la construcción del sujeto negro: el racismo y la...

Fröbel, Julius. Seven Years' Travel in Central America, Northern Mexico, and the Far West of the United States. London: Richard Bentley, 1859.

Gisborne, Lionel. The Isthmus of Darien in 1852. Journal of the Expedition of Inquiry for the Junction of the Atlantic and Pacific Oceans. With Four Maps. London: Saunders and Stanford, 1853.

Gosselman, Carl August. Viaje por Colombia. 1825 y 1826. Bogotá: Banco de la República, 1981.

Gómez Creutzberg, Carla, Viajeros y espacios en disputa. Frederick A. A. Simons y el Caribe colombiano a finales del siglo XIX. Bogotá: Universidad Externado de Colombia, 2017.

Kempadoo, Kamala (Editor). Sun, Sex and Gold. Tourism and Sex Work in the Caribbean. Oxford: Rowman and Littlefield. 1999.

Leclerc de Buffon, Georges Louis. Histoire naturelle, générale et particulière, T. 14. Paris: Nouvelle Société Typographique, 1785.

Hall, Francis. Colombia: Its Present State, in Respect of Climate, Soil, Productions, Population, Government, Arts, Literature, Manners, Education, and Inducement to Emigration. Philadelphia: A. Small, E. Parker, E.Littell, and Marot \& Walter, 1825.

Hill, S. S. Travels in Peru and Mexico, vol. 2. London: Spottiswoode and Co., 1860.

Holton, Isaac F. New Granada: twenty months in the Andes. New York: Harper \& brothers, 1857.

Le Moyne, Auguste. Viajes y estancias en América del Sur, la Nueva Granada, Santiago de Cuba, Jamaica y el Istmo de Panamá. Bogotá: Ministerio de Educación, 1945.

Lisboa, Miguel María. Relación de un viaje a Venezuela, Nueva Granada y Ecuador. Bogotá: Fondo Cultural Cafetero, 1984.

Mollien, Gaspard. Viaje por la República de Colombia en 1823. Bogotá: Ministerio de Educación, 1944.

Múnera, Alfonso. Fronteras imaginadas. La construcción de las razas y de la geografia en el Siglo XIX colombiano. Bogotá: Editorial Planeta, 2005.

Niño Vargas, Camilo Juan. Indios y viajeros: Los viajes de Joseph de Brettes y Georges Sogler por el norte de Colombia 1892-1896. Bogotá: Universidad de los Andes, 2017. 
Páez, Ramón. Travels and Adventures in South and Central America. With Life in the Llanos of Venezuela. Hartford: T. Belknap, 1873.

Pérez, Santiago. Apuntes de viaje. Segundo artículo. El Neogranadino, Dic. 1, 1853.

Pérez Mejía, Á. La geografía de los tiempos difíciles: escritura de viajes a Sur América durante los procesos de independencia 1780-1849. Medellín: Universidad de Antioquia, 2002.

Nobles, Melissa. Shades of Citizenship: Race and the Census in Modern Politics. Stanford: Stanford University Press, 2000.

Pratt, Mary Louise. Imperial Eyes: Travel Writing and Transculturation. London and New York: Routledge, 1992.

Reclús, Eliseo. Viaje a la Sierra Nevada de Santa Marta. Bogotá: Ministerio de Educación, 1947.

Saffray, Charles. Voyage à la Nouvelle Grenade. S. Edi: 1869. https://archive.org/ details/VoyageaLaNouvelleGrenade/page/n112/mode/1up

Saffray, Charles. Viaje a Nueva Granada. Bogotá: Ministerio de Educación, 1948.

Sanders, James. The Vanguard of the Atlantic World. Creating Modernity, Nation, and Democracy in Nineteenth-Century Latin America. Durham: Duke University Press, 2014.

Scott, James C. Los dominados y el arte de la resistencia. Discursos ocultos. Ciudad de México: Ediciones ERA, 2000.

Sheller, Mimi. Citizenship from Below. Erotic Agency and Caribbean Freedom. Durham: Duke University Press, 2012.

Sheller, Mimi. Consuming the Caribbean: From Arawaks to Zombies. Abingdon: Routledge, 2003.

Stanley, Edward Henry. Six Weeks in South America. London: T. and W. Boone, 1850.

Tanco Armero, Nicolás. Viaje de Nueva Granada a China y de China a Francia. Paris: Imprenta de Simon Raçon y Comp, 1861.

Trouillot, Michel Rolph. Silenciando el pasado. El poder y la producción de la Historia. Albolote: Comares, 2017.

Wade, Peter. Raza y etnicidad en América Latina. Quito: Ediciones Abya Yala, 2000. 
La imagen de las personas racializadas y la construcción del sujeto negro: el racismo y la...

\section{Capítulos de libro}

Angulo, Felipe. "Viajeros franceses del siglo XIX en Colombia. Un balance bibliográfico", http://www.afehc-historia-centroamericana.org/index_action_fi_ aff_id_1649.html

Burke, Peter. "Estereotipos de los otros", en Visto y no Visto. El uso de la imagen como documento histórico (Traducción de Teófilo de Lozoya), Barcelona, Crítica, 2005.

Gómez, Leguis. “Clase, etnia y región: el Caribe Novogranadino y la mirada del 'Otro'. 1750-1830”, Artelogie. Recherche sur les arts, le patrimoine et la littérature de l'Amérique latine, 9, (2016) 1-28.

\section{Artículos de revistas}

Estivariz, María C., y Migoya, María Alejandra. "Ilustrando la naturaleza", Museo, 3, 19 (2005): $90-95$.

Giraldo Jaramillo, Gabriel, "Viajeros franceses en Colombia”, en Estudios históricos (1954): 187-212.

Gómez García, Juan Guillermo, "Stübel y Reiss : dos viajeros alemanes en la Colombia del siglo XIX”, Boletín Cultural y Bibliográfico 31, 35 (1994): 3-27

Guerra, Adriano. "El imperio invisible. Los mosquitos en el Caribe colombiano vistos por los viajeros extranjeros del siglo XIX”, Memorias, 16, 41 (2020) 103-129.

Jaramillo Uribe, Jaime, "La visión de los otros: Colombia vista por observadores extranjeros en el siglo XIX", Historia Crítica, 1, 24 (2003): 7-21.

McKennan, Theodora, "Jeremy Bentham and the Colombian Liberators," The Americas, 34, 4 (1978): 460-475.

Mora, Ángela Rocío, "Pasto y sus gentes en el siglo XIX: de la percepción de los viajeros a la construcción de un imaginario social en Colombia", Procesos Históricos, 21 (2018): 94-107.

Mora Pacheco, Katherinne Giselle. "Monotonía, aislamiento y atraso agrícola. Descripciones de viajeros del siglo XIX e historia agraria de la Sabana de Bogotá (Colombia)", HiSTOReLo. Revista de Historia Regional y Local, 7, 14 (2015): 180-213.

Muñoz Arbeláez, Santiago. "Las imágenes de viajeros en el siglo XIX: El caso de los grabados de Charles Saffray sobre Colombia”, Historia y grafia, 34 (2010). 
Olave Quintero, Viviana. "Viajeros de la avanzada del capitalismo. La visión de Gaspard Théodore Mollien sobre la política de la Nueva Granada en la postindependencia", Historia y espacio, 5, 33 (2009).

Villegas, Álvaro. "El valle del río Magdalena en los discursos letrados de la segunda mitad del siglo XIX: territorio, enfermedad y trabajo", Folios, 39 (2014).

\section{Tesis, ponencias y otros}

Ávila Camargo, Diana Yaneth. "Relatos de viajeros colombianos: imaginarios, representación y territorio, 1850 - 1860" (Tesis de Maestría) Universidad Andina Simón Bolívar, 2012.

Camargo Mesa, Marcela. "Viajeros europeos en Bogotá 1869-1900, experiencias de viaje y observación de la sociedad en las calles" (Monografía de pregrado) Pontificia Universidad Javeriana, 2009.

Gallón, Julián David. "El rio Magdalena. Visto por viajeros franceses e ingleses, 1823-1871." (Monografía de pregrado) Universidad de Antioquia, 2009.

Melo, Jorge Orlando, "La mirada de los franceses: Colombia en los libros de viaje durante el siglo XIX", ponencia presentada en Simposio: Viajeros colombianos en Francia y franceses en Colombia, Paris, 2001.

Torres Torres, Camila. "La imagen de Bogotá construida por los viajeros extranjeros que recorrieron el país a lo largo del Siglo XIX". (Tesis de Maestría) Pontificia Universidad Javeriana, 2009. 